\title{
Kaolinite and hematite flotation separation using etheramine and ammonium quaternary salts
}

\author{
Otávia Martins Silva Rodrigues ${ }^{\mathrm{a}, *}$, Antônio Eduardo Clark Peres ${ }^{\mathrm{b}}$, Afonso Henriques Martins ${ }^{\mathrm{b}}$, \\ Carlos Alberto Pereira ${ }^{a}$ \\ ${ }^{a}$ Departamento de Engenharia de Minas, Universidade Federal de Ouro Preto, Brazil \\ ${ }^{\mathrm{b}}$ Departamento de Engenharia Metalúrgica e de Materiais, Universidade Federal de Minas Gerais, Brazil
}

\section{A R T I C L E I N F O}

\section{Article history:}

Received 9 December 2011

Accepted 17 September 2012

Available online 7 November 2012

\section{Keywords:}

Flotation collectors

Froth flotation

Kaolinite

Hematite

\begin{abstract}
A B S T R A C T
Clay minerals are widespread in various types of mineral deposits. When present, they contribute to the high content of certain parameters such as silica, aluminium, and magnesium. This study aimed to find selectivity windows to separate hematite from a clay mineral (kaolinite) to allow reduction of the levels of silica and alumina in iron ore. The collectors used were: etheramine Flotigam EDA (EDA) and the ammonium quaternary salts: dodecyltrimethylammonium bromide (DTAB) and Tomamine Q-14-2 PG (AQ142). The depressant used was corn starch. The separation selectivity was achieved using DTAB in the $\mathrm{pH}$ range between 4 and 10 . Using the collectors EDA and AQ142, the selectivity was obtained only in the presence of starch, at pH 10. Laboratory scale tests showed that as far as the particles size is concerned, better selectivity was achieved with finer particles. Circuit configurations including cleaner and scavenger stages, and pilot scale tests, will be required prior to a possible industrial implementation of the separation.
\end{abstract}

(c) 2012 Elsevier Ltd. All rights reserved.

\section{Introduction}

In most of the countries in the world one can observe the increase of industrial segments, like automotive, manufacturing, and civil construction. To maintain this growth, it is necessary to supply the demand of steel, consequently, of iron ore.

Clay minerals are widespread in various types of mineral deposits. When present, they contribute to the high content of certain parameters such as silica, aluminium and magnesium. The presence of kaolinite, a clay mineral, has contributed to increase the grade of silica and aluminium in Brazilian and Australian iron ores (Ma et al., 2009).

Kaolinite $\left(\mathrm{Al}_{2} \mathrm{Si}_{2} \mathrm{O}_{5}(\mathrm{OH})_{4}\right)$ is the main mineral in kaolin ores and is very common, as gangue mineral, in bauxite ores. In the current literature, there are many articles addressing the removal of kaolinite from bauxite ores. Amines and ammonium quaternary salts are the types of collector mostly used to float kaolinite from bauxite ores (Wang et al., 1999; Cao et al., 2009; Hu et al., 2003, 2008; Xu et al., 2004; Zhaohui and Gallus, 2007; Jiang et al., 2011). However, information on removing kaolinite from iron ores is scarce.

\footnotetext{
* Corresponding author. Address: Departamento de Engenharia de Minas, Universidade Federal de Ouro Preto, Campus Morro do Cruzeiro, Bauxita, Ouro Preto 35.400-000, Brazil. Tel.: +55 3188171146 .

E-mail address: otaviamartins@yahoo.com.br (O.M.S. Rodrigues).
}

Kaolinite is the most common clay mineral in Brazilians iron ores. Most of the beneficiation plants remove kaolinite (and other aluminosilicates) in the desliming stage. This is a consequence of the size of kaolinite particles. Despite using the desliming stage, the presence of a high $\mathrm{Al}_{2} \mathrm{O}_{3}$ grade is common. In these cases, the removal of kaolinite in the concentration stage may be a good alternative. Due to the small size of kaolinite particles, their removal via flotation is more indicated than through magnetic separation.

There is a wide knowledge about separation of quartz from iron ore. Despite the fact that quartz and kaolinite belong to the silicates class, they do not present similar behaviours in an industrial flotation process, probably due to the face-edge structure present only in the kaolinite structure (Ma et al., 2009). According to Araujo et al. (2003) it is not trivial to separate kaolinite from iron ores. In most of the cases kaolinite particles are not amenable to flotation concentration, in the other words the kaolinite content is just partitioned according to the pulp flow. Rodrigues (2009) stated that the kinetics of flotation is a critical point to achieve selective flotation of kaolinite. She showed that two amines (dodecylamine and Flotigam EDA) and two ammonium quaternary salts (cetylpiridinium choride and cetyltrimetylammonium bromide) are efficient as collector of both, kaolinite and quartz, however the span of time required to float kaolinite was approximately 5-10 times longer than that necessary to float quartz (depending on the collector type). Also, the author discussed the influence of increasing the 
flotation time in an industrial process, what can cause many problems, for instance, the flotation of hematite resulting in selectivity losses.

Ma (2010, 2011a and b) discussed aspects related to kaolinite separation in iron ore processing. Ma (2011a) showed that when hydrolysable metal cations such as $\mathrm{Ca}$ and $\mathrm{Mg}$ are present in the process water they cause a strong coagulation of kaolinite particles and sodium silicate cannot effectively disperse this pulp, resulting in selectivity losses. Furthermore, in an anterior paper, Ma (2010) showed that, considering concentration of cations above $0.001 \mathrm{~mol} / \mathrm{L}$, the presence of starch in low dosages intensifies the coagulation phenomenon, but the corn starch re-disperses the kaolinite in higher dosages. The presence of cations renders the zeta potential of kaolinite particles less negative at $\mathrm{pH} 10.5$, consequently it favours the coagulation. High dosage of starch causes the opposite effect due to steric forces between the kaolinite particles coated with starch. In a third article, Ma (2011b) suggested a low-molecular-weight polyacrylic acid (MW1800 by Sigma) as good dispersant for kaolinite under typical conditions of iron ore flotation and selective flocculation.

In a general scenario there were some advances concerning this issue, but the background in the academic group should be further improved. This study aimed to find selectivity windows, using microflotation experiments, to separate hematite from kaolinite to allow reduction of the levels of silica and alumina in iron ores when kaolinite is present as gangue. Also, laboratory scale tests were done to check if the conditions observed in microflotation could be reproduced in bench scale.

\section{Methodology}

Microflotation tests were conducted with the use of a Hallimond tube using pure minerals (kaolinite and hematite) to evaluate the performance of collectors and depressants in the system.

The samples were carefully milled, avoiding fines production and contamination, using an agate mortar and pestle. The particles size of the samples was adjusted between $75 \mu \mathrm{m}$ and $212 \mu \mathrm{m}$.

The agitation in the Hallimond tube causes further comminution of the already fine kaolinite particles, so an extension was adapted to the apparatus to prevent entrainment. $\mathrm{N}_{2}$ was the gas used to produce the bubbles, at a flow rate of $50 \mathrm{~mL} / \mathrm{min}$.

Throughout this study four amines and four ammonium quaternary salts were tested. This article presents just the results with

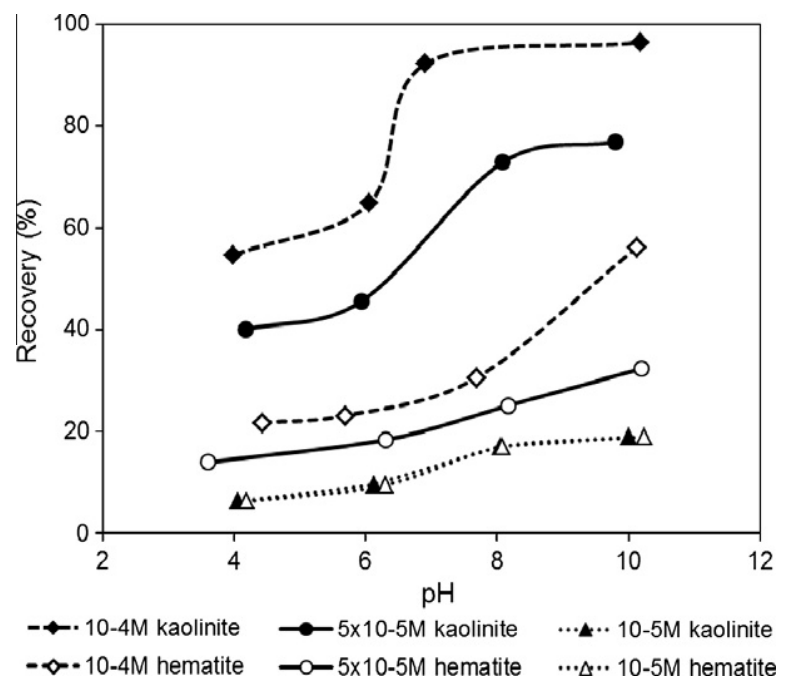

Fig. 1. Floatability of kaolinite and hematite as a function of $\mathrm{pH}$ and EDA concentration. the collectors that showed selectivity at the microflotation stage. The best collectors were: the etheramine Flotigam EDA (EDA); and the ammonium quaternary salts: dodecyltrimethylammonium bromide (DTAB) and Tomamine Q-14-2 PG (AQ142). EDA and AQ142 are commercial collectors produced by, respectively, Clariant and Pietsch Chemicals. DTAB is a pure reagent produced by $\mathrm{Al}-$ drich Chemistry. Gelatinised corn starch was used as depressant.

The collectors performance was evaluated at three concentrations: $1 \times 10^{-4} \mathrm{~mol} / \mathrm{L}, 5 \times 10^{-5} \mathrm{~mol} / \mathrm{L}$, and $1 \times 10^{-5} \mathrm{~mol} / \mathrm{L}$. The collectors conditioning time was one minute. The performance of corn starch was checked at a concentration range between $10 \mathrm{mg} / \mathrm{L}$ and $400 \mathrm{mg} / \mathrm{L}$. The depressant conditioning time was $2 \mathrm{~min}$. The froth collection time was determined after kinetic experiments, and established at $5 \mathrm{~min}$ for the tests using EDA and DTAB, and 2 min for the tests using AQ142. These experiments were done at $\mathrm{pH}$ values close to $4,6,8$ and 10 .

Laboratory scale flotation tests were conducted to verify the reproducibility of the results indicated in the microflotation stage. The sample consisted of a blend of iron ore (90\%) and kaolin (10\%). These tests were done in a Denver machine using a $900 \mathrm{~mL}$ cell.

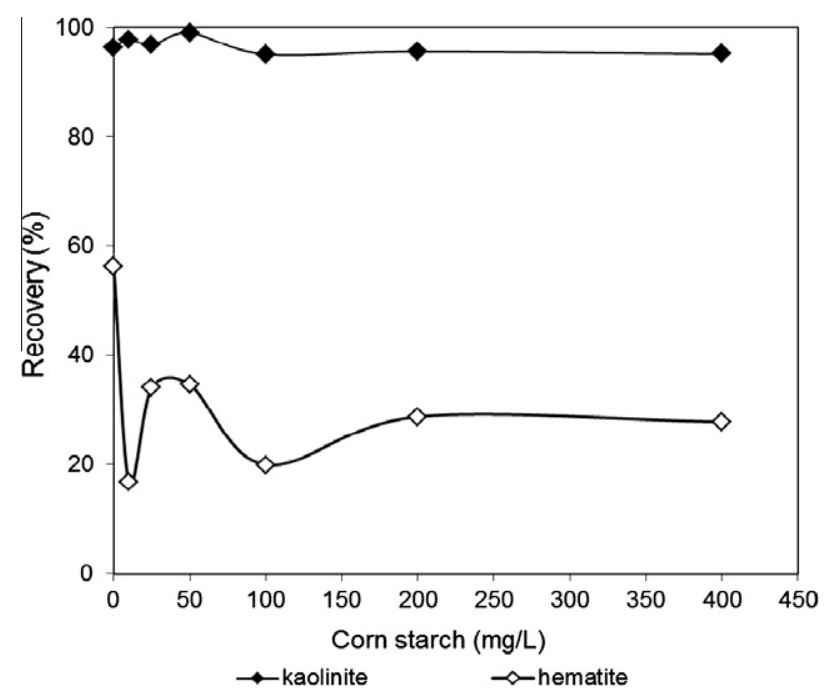

Fig. 2. Floatability of kaolinite and hematite, as a function of starch concentration, with $\operatorname{EDA}\left(1 \times 10^{-4} \mathrm{~mol} / \mathrm{L}\right)$ at $\mathrm{pH}=10$.

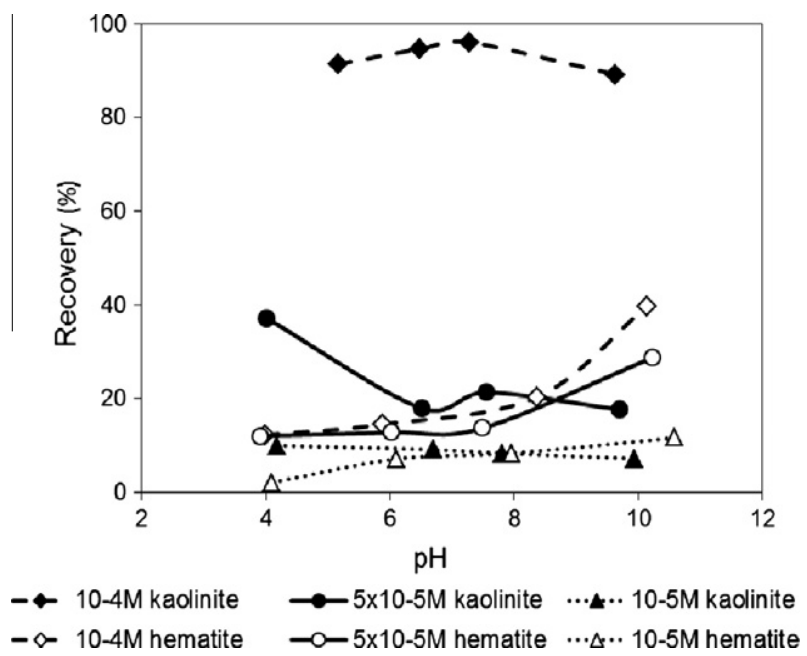

Fig. 3. Floatability of kaolinite and hematite as a function of $\mathrm{pH}$ and DTAB concentration. 


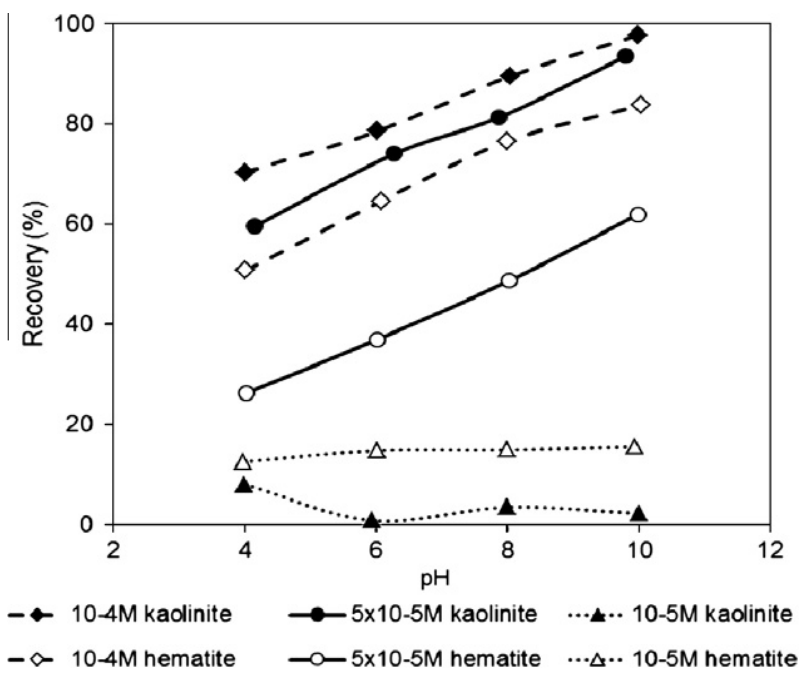

Fig. 4. Floatability of kaolinite and hematite as a function of $\mathrm{pH}$ and AQ142 concentration.

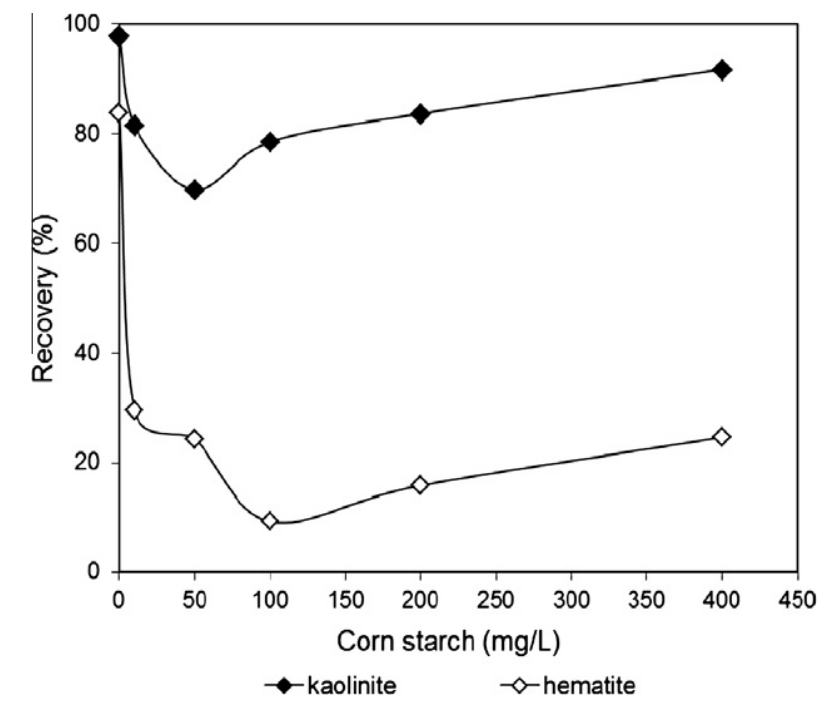

Fig. 5. Floatability of hematite and kaolinite, with AQ142 $\left(1 \times 10^{-4} \mathrm{~mol} / \mathrm{L}\right)$, as a function of starch concentration, at $\mathrm{pH}=10$.

Each test was fed with $270 \mathrm{~g}$ of iron ore, $30 \mathrm{~g}$ of kaolin and $700 \mathrm{~mL}$ of water. The gas flow rate was $6 \mathrm{NL} / \mathrm{min}$. A strong agitation stage ( $2 \mathrm{~min}$ ) was used to homogenise the feed prior to the reagents conditioning ( $5 \mathrm{~min}$ for depressant and $2 \mathrm{~min}$ for collector). These experiments were done at $\mathrm{pH}$ values close to 7 and 10 . Bench scale tests were conducted in two size ranges: $-150 \mu \mathrm{m}$ deslimed and $-45 \mu \mathrm{m}$.

Both stages, microflotation and laboratory scale, were conducted with distilled water.

\section{Results and discussion}

\subsection{Microflotation experiments}

Fig. 1 presents the floatability of kaolinite and hematite as a function of $\mathrm{pH}$, considering the three concentrations of EDA tested. The separation of these two minerals is not possible in the absence of depressant. Fig. 2 shows the results of adding corn starch to the system, at $\mathrm{pH}=10$. The presence of depressant resulted in selective separation. One can verify a selectivity window of approximately $65 \%$ in, practically, every condition investigated. These conditions are similar to those used in the industrial process, in terms of reagents and $\mathrm{pH}$. Many Brazilian plants use the etheramine EDA as a collector of quartz, sometimes mixed with other amines.

Fig. 3 shows the recovery of kaolinite and hematite, using the collector DTAB, as a function of pH considering the three concentrations tested. The results showed that the separation between kaolinite and hematite is possible in the full range of $\mathrm{pH}$, just for the concentration of collector equal to $1 \times 10^{-4} \mathrm{~mol} / \mathrm{L}$. Zhao et al. (2007), using an ammonium quaternary salt (cetyltrimtylammonium bromide - CTAB) as a collector of aluminosilicate (including kaolinite), reached similar result, floatability of kaolinite were between $80 \%$ and $90 \%$ at $\mathrm{pH}$ range between 4 and 10 . CTAB and DTAB differ from each other in that the first has carbon chain composed by 16 carbons and the second has 12 carbons. Also, it was observed that the selectivity decreases with the increase of $\mathrm{pH}$ due to the increase in the hematite recovery. The selectivity windows is, approximately, $80 \%$ at $\mathrm{pH}=4$ and decreases to, approximately, $50 \%$ at $\mathrm{pH}=10$.

Fig. 4 illustrates the recovery of kaolinite and hematite, using the collector AQ142, as a function of $\mathrm{pH}$ considering the three concentrations tested. The results shown in Fig. 4 indicate that the separation is not possible. However, the Fig. 5 shows that the addition of corn starch results in a selectivity window of, approximately, $60 \%$. As AQ142 is a new collector this result represents a significant contribution to the literature.

\subsection{Laboratory scale experiments}

The $\mathrm{Al}_{2} \mathrm{O}_{3}$ and $\mathrm{SiO}_{2}$ grades of the iron ore were, respectively, $0.34 \%$ and $1.04 \%$. Due to the low $\mathrm{Al}_{2} \mathrm{O}_{3}$ content, this parameter was chosen to evaluate the kaolinite separation from the feed blend $\left(3.78 \% \mathrm{Al}_{2} \mathrm{O}_{3}\right)$. This stage was conducted in two size ranges: (i) coarse, particles size less than $-150 \mu \mathrm{m}$ and deslimed (ii) fine, particles size $-45 \mu \mathrm{m}$. In the first case aggregates of kaolinite were present (this alternative simulates the feed of common industrial

Table 1

Results of laboratory scale flotation tests with feed size $-150 \mu \mathrm{m}$ deslimed.

\begin{tabular}{|c|c|c|c|c|c|c|c|c|c|c|}
\hline Test & $\mathrm{pH}$ & Collector & Depressant & Product & $\mathrm{Fe}(\%)$ & $\mathrm{SiO}_{2}(\%)$ & $\mathrm{Al}_{2} \mathrm{O}_{3}(\%)$ & Fe $\operatorname{Rec}(\%)$ & $\mathrm{Al}_{2} \mathrm{O}_{3} \operatorname{Rec}(\%)$ & Mass Rec (\%) \\
\hline 3 & 7 & DTAB $400 \mathrm{~g} / \mathrm{t}$ & $\mathrm{X}$ & $\begin{array}{l}\text { Reject } \\
\text { Concentrate } \\
\text { Feed }\end{array}$ & $\begin{array}{l}59.95 \\
68.13 \\
62.47\end{array}$ & $\begin{array}{l}6.25 \\
1.20 \\
4.69\end{array}$ & $\begin{array}{l}4.60 \\
0.72 \\
3.41\end{array}$ & 33.60 & 6.51 & 30.80 \\
\hline 12 & 10 & EDA $400 \mathrm{~g} / \mathrm{t}$ & Corn starch $600 \mathrm{~g} / \mathrm{t}$ & $\begin{array}{l}\text { Reject } \\
\text { Concentrate } \\
\text { Feed }\end{array}$ & $\begin{array}{l}54.94 \\
65.02 \\
61.35\end{array}$ & $\begin{array}{l}9.58 \\
2.90 \\
5.33\end{array}$ & $\begin{array}{l}7.26 \\
1.94 \\
3.88\end{array}$ & 67.37 & 31.79 & 63.56 \\
\hline 20 & 10 & AQ142 $400 \mathrm{~g} / \mathrm{t}$ & Corn starch $400 \mathrm{~g} / \mathrm{t}$ & $\begin{array}{l}\text { Reject } \\
\text { Concentrate } \\
\text { Feed }\end{array}$ & $\begin{array}{l}58.47 \\
67.03 \\
62.15\end{array}$ & $\begin{array}{l}7.54 \\
1.95 \\
5.14\end{array}$ & $\begin{array}{l}5.40 \\
1.55 \\
3.75\end{array}$ & 46.36 & 17.79 & 42.98 \\
\hline
\end{tabular}


Table 2

Results of laboratory scale flotation tests with feed size $-45 \mu \mathrm{m}$.

\begin{tabular}{|c|c|c|c|c|c|c|c|c|c|c|}
\hline Test & $\mathrm{pH}$ & Collector & Depressant & Product & $\mathrm{Fe}(\%)$ & $\mathrm{SiO}_{2}(\%)$ & $\mathrm{Al}_{2} \mathrm{O}_{3}(\%)$ & Fe $\operatorname{Rec}(\%)$ & $\mathrm{Al}_{2} \mathrm{O}_{3} \operatorname{Rec}(\%)$ & Mass Rec (\%) \\
\hline 24 & 7 & DTAB $400 \mathrm{~g} / \mathrm{t}$ & $\mathrm{X}$ & $\begin{array}{l}\text { Reject } \\
\text { Concentrate } \\
\text { Feed }\end{array}$ & $\begin{array}{l}59.22 \\
67.76 \\
61.05\end{array}$ & $\begin{array}{l}6.96 \\
1.02 \\
5.68\end{array}$ & $\begin{array}{l}5.04 \\
0.81 \\
4.13\end{array}$ & 23.83 & 4.21 & 21.47 \\
\hline 33 & 10 & EDA $400 \mathrm{~g} / \mathrm{t}$ & Corn starch $600 \mathrm{~g} / \mathrm{t}$ & $\begin{array}{l}\text { Reject } \\
\text { Concentrate } \\
\text { Feed }\end{array}$ & $\begin{array}{l}57.55 \\
67.40 \\
61.29\end{array}$ & $\begin{array}{l}8.06 \\
1.56 \\
5.59\end{array}$ & $\begin{array}{l}5.92 \\
1.14 \\
4.11\end{array}$ & 41.72 & 10.53 & 37.94 \\
\hline 38 & 10 & AQ142 $400 \mathrm{~g} / \mathrm{t}$ & Corn starch $400 \mathrm{~g} / \mathrm{t}$ & $\begin{array}{l}\text { Reject } \\
\text { Concentrate } \\
\text { Feed }\end{array}$ & $\begin{array}{l}58.58 \\
66.58 \\
61.10\end{array}$ & $\begin{array}{l}7.37 \\
1.70 \\
5.58\end{array}$ & $\begin{array}{l}5.23 \\
1.12 \\
4.00\end{array}$ & 34.34 & 8.83 & 31.52 \\
\hline
\end{tabular}

flotation of iron ore). The second case simulates the condition of slimes flotation. Tables 1 and 2 present the bests results with each collector. These tables differ from each other in that Table 1 shows the results of tests with feed size $-150 \mu \mathrm{m}$ deslimed and Table 2 shows the results of tests with feed size $-45 \mu \mathrm{m}$.

Two differences may be observed. Firstly, with the decrease of feed size, the selectivity increases, as shown by the lower contaminants grades in the concentrates of tests using feed size $-45 \mu \mathrm{m}$. This enhanced selectivity of the fines is desirable, for the kaolinite low hardness causes the production of fines in the comminution stages.

Secondly, the finer size caused a decrease in the mass recovery in all situations, consequently, yielding decreased recovery of Fe. Also, the reject fraction iron grade was still high (approximately $50 \%$, well above the grade acceptable in industrial scale. This high iron content is partially due to the high iron feed grade (61\%). Circuit configurations including cleaner and scavenger stages, and pilot scale tests, will be required prior to a possible industrial implementation of the separation. On the other hand, silica grades in the concentrate in the range from $1.0 \%$ to $1.5 \%$ were achieved, figures compatible with iron ore concentrates specifications.

It is important to stress that the kaolinite content in the synthetic ore feeding the laboratory scale flotation tests represents an ultimate condition, being much higher than the content in ores that are processed in actual plant practice.

\section{Conclusion}

The separation selectivity between kaolinite and hematite was achieved using DTAB at the pH range between 4 and 10 . In the presence of the collectors EDA and AQ142, the selectivity was obtained only in the presence of starch, at pH 10. Laboratory scale tests showed that as far as the particles size is concerned, better selectivity was achieved with finer particles. Circuit configurations including cleaner and scavenger stages, and pilot scale tests, will be required prior to a possible industrial implementation of the separation.

\section{Acknowledgements}

The authors are grateful to CNPq for the financial support.

\section{References}

Araujo, A.C., Amarante, S.C., Souza, C.C., Silva, R.R.R., 2003. Ore mineralogy and its relevance for iron methods in processing of Brazilian iron ores. Mineral Processing and Extractive Metallurgy 112, C54-C64.

Cao, X., Liu, C., Hu, Y., 2009. Flotation of kaolinite with dodecyl tertiary amines. Journal of Central South University Technology 16, 749-752.

Hu, Y., Jiang, H., Wang, D., 2003. Electrokinetic behavior and flotation of kaolinite in CTAB solution. Minerals Engineering 16, 1221-1223.

Hu, Y., Ouyang, K., Cao, X., Zhang, L., 2008. Flotation of kaolinite and diaspore with hexadecyl dimethyl benzyl ammonium chloride. Journal of Central South University Technology 15, 378-381.

Jiang, H., Xu, L., Hu, Y., Wang, D., Li, C., Meng, W., Wang, X., 2011. Flotation and adsorption of quaternary ammonium cationic collectors on diaspora and kaolinite. Transactions Nonferrous Metallurgical Society China 21, 2528-2534.

Ma, X., Bruckard, W.J., Holmes, R., 2009. Effect of collector, pH and ionic strength on the cationic flotation of kaolinite. International Journal of Mineral Processing $93,54-58$.

Ma, X., 2010. Role of hydrolysable metal cations in starch-kaolinite interactions. International Journal of Mineral Processing 97, 100-103.

Ma, M., 2011a. Enhancement of hematite flocculation in the hematite-starch-(lowmolecular-weight) Poly(acrylic acid) system. Industrial \& Engineering Chemistry Research 50, 11950-11953.

Ma, X., 2011b. Effect of a low-molecular-weight polyacrylic acid on the coagulation of kaolinite particles. International Journal of Mineral Processing 99, 17-20.

Rodrigues, O.M.S., 2009. Study on Kaolinite Flotation. Belo Horizonte: Escola de Engenharia da Universidade Federal de Minas Gerais, 96p (M.Sc. Thesis in Metallurgical and Mining Engineering, in Portuguese).

Wang, J., Han, B., Dai, M., Yan, H., Li, Z., Thomas, R.K., 1999. Effects of chain length and structure of cationic surfactants on the adsorption onto $\mathrm{Na}$-Kaolinite. Journal of Colloid and Interface Science 213, 596-601.

Xu, Z., Plitt, V., Liu, Q., 2004. Recent advances in reverse flotation of diasporic ores a Chinese experience. Minerals Engineering 17, 1007-1015.

Zhaohui, L., Gallus, L., 2007. Adsorption of dodecyl trimethylammonium and hexadecyl trimethylammonium onto kaolinite - competitive adsorption and chain length effect. Applied Clay Science 35, 250-257.

Zhao, S., Shong, H., Liu, G., 2007. Effect of ammonium salts on flotation behaviour of aluminisilicate minerals. Journal of Central South University Technology 04 0500-0504. 